Scientific Journal of October 6 University

ISSN (Print): 2314-8640

ISSN (Electronic): 2356-8119

Published by October 6 University @ All Rights Reserved

Available online at: http:// sjou.journals.ekb.eg
Citation: Elkharbotly et al., (2016). Techno-Economic Comparison among Methods of Organic Matter Removal in Water Treatment. Sci.J. of Oct. 6 Univ. 3(1), 75-80.

Copyright: (c) 2016 Elkharbotly et al., This is an open-access article distributed under the terms of the Creative Commons Attribution License, which permits unrestricted use, distribution, and reproduction in any medium, provided the original author and source are credited.

Original Article

\title{
Techno - Economic Comparison among Methods of Organic Matter Removal in Water Treatment
}

\section{Elkharbotly, M. Abdel Razik, M. Fergala and E.Wahb}

Sanitary\& Environmental Engineering Section, Faculty of Engineering, Ain Shams University, Cairo.

Received: 8-11-2014/ Revised: 14-12-2014 / Accepted: 20-01-2015

\begin{abstract}
This research aims to investigate the best method to use for upgrading existing water treatment plants in Egypt to be able to remove natural organic matter (NOM) based on a techno-economic comparison. Three methods are selected namely: granular activated carbon (GAC), ultrafiltraton (UF) and ion exchange (IEX). The technical comparison considered the performance, need for skilled workers, ability to deal with shock loads, waste production, O\&M needed time and life time of the media. The financial comparison considered capital cost, running cost and media/membrane regeneration or replacement. The analysis results indicated that the UF is the most effective method from the technical point of view followed by IEX then GAC. However from the financial point of view, GAC is the cheapest method $\left(0.16 \mathrm{LE} / \mathrm{m}^{3}\right)$, followed by $\operatorname{IEX}\left(0.33 \mathrm{LE} / \mathrm{m}^{3}\right)$ then $\mathrm{UF}\left(0.53 \mathrm{LE} / \mathrm{m}^{3}\right)$.
\end{abstract}

Key Words: Ultra filtration, Granular Activated Carbon, Ion Exchange, Natural Organic Matter.

\section{Introduction}

Natural organic matters (NOM) include humic substances, hydrophilic acids and organic compounds. NOM has no direct measurement, but total organic carbon (TOC) can be considered a reasonable indicator of organic content. River Nile water quality results indicate high TOC concentration ranging from 5.5 to $8 \mathrm{mg} / \mathrm{L}$ for years 2010 and 2011 which violates the U.S. Drinking Water Standard of $5.0 \mathrm{mg} / \mathrm{L}$ as shown in Figure (1), M.Reda-2012.

Nub aria Canal has several agricultural drains discharging into it at various locations, Nub aria Canal suffers from high values of BOD and COD that violate the standards of Law 48 of BOD (10 $\mathrm{mg} / \mathrm{L})$ and COD (15 mg/L) as shown in Table (1) and Figure (2), $M H W-2009$.
Existing conventional water treatment plants in Egypt are not designed for removal of NOM, water quality analysis of raw and treated water show removal percentage of maximum $30 \%$.

NOM compounds are known to react with chlorine and chloramines to produce disinfection byproducts (DBPs) such as trihalom ethanes (THMs). NOM also causes tastes, odors and color, and may present potential health concerns. Water containing NOM promotes biological growth in distribution systems.

Therefore, it is important that WTP's be upgraded to deal with such new pollutant. Three methods are investigated namely: granular activated carbon, ultra filtration, and ion exchange.

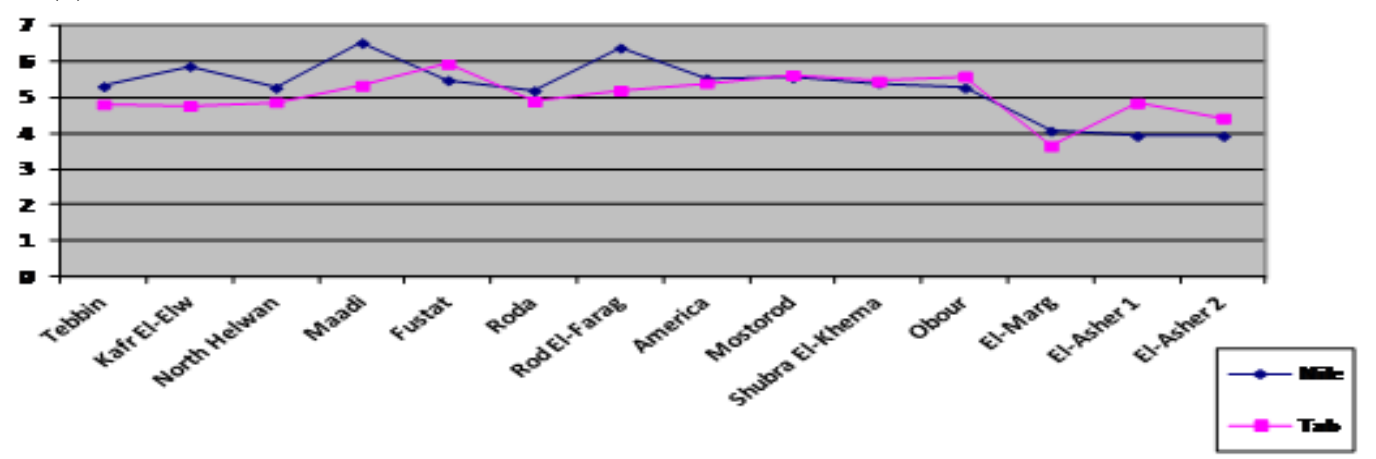

Figure (1): Maximum TOC of Greater Cairo WTP's from January to December 2011 
Table (1): Inflowing Drains to Nubaria Canal

\begin{tabular}{|l|l|l|}
\hline Location Code & Km & Description \\
\hline WN-13 & 5 & Delengat Extension PS at km 5 \\
\hline WN-11 & 25 & Bustan PS. At km 25, \\
\hline WN-03 & 51 & El Nasr 3 (Drain No 3) at km 51, \\
\hline WN-01 & 55 & El Nasr 1 (Drain No 1) at km 55.5 \\
\hline WU-10 & 85 & Mariut Khalt PS. at km 85.1 \\
\hline
\end{tabular}

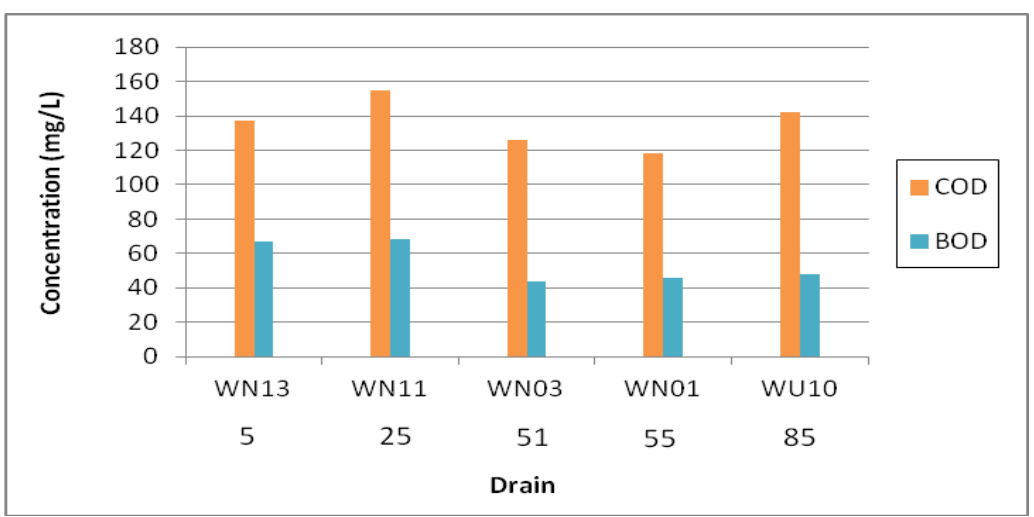

Figure (2): BOD and COD in Inflowing drains to nubaria canal

Many water treatment processes are in common use to remove NOM. These include coagulation-based systems such as conventional treatment, oxidationbased systems, membrane-based systems and adsorption-based systems (activated carbon, IEX).

\section{Membrane Technology}

The membrane separation process is based on the presence of semi permeable membranes. The membrane acts as a very specific filter with pores sized to permit the passage of water molecules, but small enough to retain a wide range of particulate and dissolved compounds, depending on their nature. Membrane filtration processes are classified according to the membrane pore sizes, which dictate the size of particles they are able to retain as shown in Figure (3).

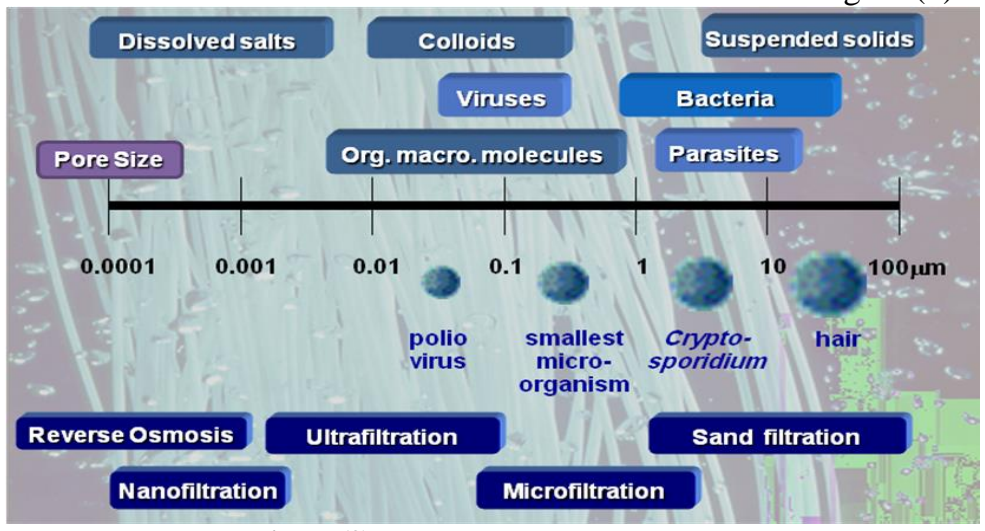

Figure (3): Membrane Treatment Types

Imai et al. 2001, stated that membrane systems are now available in several different forms and sizes, each uniquely fitting a particular need and application. Table (2) gives a quick overview of membrane types. 
Table (2): Membranes types

\begin{tabular}{|l|l|l|c|}
\hline Filtration class & $\begin{array}{l}\text { Particle capture } \\
\text { size }(\mu \mathrm{m})\end{array}$ & Typical contaminants removed & $\begin{array}{c}\text { Typical operating } \\
\text { pressure } \\
\text { ranges }\end{array}$ \\
\hline Microfiltration (MF) & $0.1-10$ & suspended solids, bacteria,protozoa & $0.2-5$ \\
\hline Ultrafiltration (UF) & $0.01-0.1$ & $\begin{array}{l}\text { colloids, proteins, polysaccharides, most } \\
\text { bacteria, viruses (partially) }\end{array}$ & $1-7$ \\
\hline Nanofiltration (NF) & $0.01-.001$ & $\begin{array}{l}\text { viruses, NOM multivalent ions } \\
\text { (including hardness in water) }\end{array}$ & $5-10$ \\
\hline Reverse osmosis (RO) & $0.001-0.0001$ & $\begin{array}{l}\text { almost all impurities, including } \\
\text { monovalent ions }\end{array}$ & $10-150$ \\
\hline
\end{tabular}

AMTA 2007, reported that most MF /UF systems operate with high recoveries of $90-98 \%$. NF removes most of the organic matter $(70-95 \%)$ whereas UF rejects mainly the high molecular refractory part (30-85\%), Ángeles de la Rubia, 2007.

Chemical cleaning is the most common method for membrane washing, the choice of the cleaning agent is critical. The optimal selection depends mainly on membrane material. These agents must be able to dissolve most of the deposited materials on the surface and remove them from the surface without damaging membrane surface, thus maintaining membrane properties, Ang et al.2006.

Commercial cleaning acid (nitric, phosphoric, hydrochloric, sulphuric and citric) are often used to remove precipitated salts or scalants, while alkaline cleaning is suitable for organic fouling removal, Mohammadi et al., 2002.

\section{Activated carbon}

Reynolds 1996, stated that activated carbon (AC) is a natural material with surface properties that are both hydrophobic and oleophilic (which means, they "hate" water but "love" oil), when flow conditions are suitable, dissolved chemicals in water flowing over the carbon surface bound to the carbon surface in a thin film by either chemical or physical attraction (Van der Waals forces) while the water passes on.

Clark 1989, reported that adsorption efficiency decreases over time, the "spent" carbon, is removed and sent for re-activation treatment. This is done primarily with GAC because PAC particles are too small to be effectively re-activated. This process allows for recovery of approximately $70 \%$ of the original carbon.

The process of IEX has minimal operational energy demands and typically only requires electricity to operate small pumps for pumping fluids under low hydraulic pressure, All Consult.

IEX requires pretreatment (deoiling, precipitation softening, TSS, etc.) to avoid resin fouling and the process cannot remove nonionic dissolved species or microbes. Operation and management
Although PAC has high adsorption capacity which is 2 to 3 times less expensive than GAC and can be easily applied and does not need a special unit, but it can be only applied on small scale and it is only used for one cycle.

Although GAC has higher cost than PAC and needs a special unit, but it has higher degree of produced water purity than PAC and can be used multiple times.

There are three available methods for regeneration: thermal, steam and chemical regeneration. Thermal is commonly used, It consists of three basic steps which are drying (at $100{ }^{\circ} \mathrm{C}$ ) for 15 minutes period during which the water retained in the carbon is evaporated, baking (at $800^{\circ} \mathrm{C}$ ) for 5 minutes period during which the adsorbed material is pyrolyzed and the volatile portions are driven off and finally activating $\left(>800^{\circ} \mathrm{C}\right)$ for 10 minutes period during which the adsorbed material is oxidized and the carbon reactivated.

\section{Ion exchange}

Michael Bourke 2009, defined IEX as a rapid and reversible process in which impurity ions present in the water are replaced by ions released by an ionexchange resin. The impurity ions are taken up by the resin, which must be periodically regenerated to restore it to the original ionic form.

IEX is effectively applied with different resins to remove NOM from pretreated surface water at specific NOM fractions, such as humic and fulvic substances and neutral organic substances were preferentially removed from this water, ranging from $1 \%$ to almost $60 \%$. Neutral organic substances are removed by all resins for approximately 50\%, Cornelissen, 2007.

considerations for IEX include occasional disinfection of IEX resin with $\mathrm{NaOCl}$ or $\mathrm{H}_{2} \mathrm{O}_{2}$. Careful management of feed stream is also necessary to ensure that fouling agents such as suspended solids, scale forming materials (e.g., $\mathrm{CaSO}_{4}$ ), and oxidized metal are not present in the feed water, All Consult. 


\section{1-Technical comparison}

There are main factors that play an important role for the selection of natural organic matter removal method. The summary for the three methods is presented in Table (3).

\section{Efficiency}

UF has the highest NOM removal efficiency (90$95 \%)$ A.I. Schäfer, followed by IEX (85-95\%), Brian Bolto-2004. finally GAC with (80-85\%), Shirra-2008.

\section{Need of skilled workers}

UF and IEX are in need of skilled workers, Michael Pilutti, while GAC has no need for skilled workers, average workers can work the system perfectly, Daniel Creek,2008.

\section{Ability to deal with shock loads}

UF system is perfectly capable of dealing with the shock loads of the feeding flow followed by IEX system with mild ability while, GAC system had very small ability to deal with the same shock loads, Zimmer, 1988.

\section{Recovery percentage}

UF system has a recovery percentage range of 8599\%, Michael Pilutti. GAC has a recovery percentage range of $97-98 \%$. IEX system has a recovery percentage range of $90-95 \%$, ESTCP2011.

\section{O\&M needed time}

UF system needs around 13 to 23 days per year, Glueckstern. GAC needs around 15 days per each year, ESTCP-2011. IEX systems needs around 14 to 21 days per each year, ESTCP-2008.

\section{Area needed}

UF system needs around $0.2-0.3 \mathrm{~m}^{2} / \mathrm{m}^{3} / \mathrm{d}$ while, GAC and IEX systems needs around 0.3-0.5 $\mathrm{m}^{2} / \mathrm{m}^{3} / \mathrm{d}$.

\section{Life time of the product}

The factor which has the greatest influence on any system design is the lifetime of the product. The expected UF membrane lifetime ranges from 3 to 7 years, Edwin Zondervan-2007, which after a new membrane should be installed while, the expected GAC membrane lifetime is more than 3 years, which after generation process should be done and finally the expected IEX resin lifetime range from 3 to 5 years (4 years on the average), W. S. Miller2009.

Table (3): Technical Comparison

\begin{tabular}{|c|c|c|c|c|c|}
\hline No. & Item & Score & UF & $\mathrm{AC}$ & IEX \\
\hline \multirow{2}{*}{1} & \multirow{2}{*}{ Quality of Produced Water } & \multirow{2}{*}{20} & High & Low & $\begin{array}{c}\text { Mediu } \\
\mathbf{m}\end{array}$ \\
\hline & & & 20 & 10 & 15 \\
\hline \multirow{2}{*}{2} & \multirow{2}{*}{ Need for Skilled Workers } & \multirow{2}{*}{15} & Medium & Low & $\begin{array}{l}\text { Mediu } \\
\text { m }\end{array}$ \\
\hline & & & 10 & 15 & 10 \\
\hline \multirow{2}{*}{3} & \multirow{2}{*}{ Ability to Deal With Shock Loads } & \multirow{2}{*}{15} & high & Low & $\begin{array}{c}\text { Mediu } \\
\mathbf{m}\end{array}$ \\
\hline & & & 15 & 5 & 10 \\
\hline \multirow{2}{*}{4} & \multirow{2}{*}{ Waste Production } & \multirow{2}{*}{10} & High & Low & $\begin{array}{c}\text { mediu } \\
\mathrm{m}\end{array}$ \\
\hline & & & 5 & 10 & 8 \\
\hline \multirow{2}{*}{5} & \multirow{2}{*}{ O\&M Needed Time } & \multirow{2}{*}{10} & High & Medium & $\begin{array}{c}\text { Mediu } \\
\mathrm{m}\end{array}$ \\
\hline & & & 5 & 10 & 10 \\
\hline \multirow{2}{*}{6} & \multirow{2}{*}{ Area Needed } & \multirow{2}{*}{15} & Low & Medium & $\begin{array}{c}\text { Mediu } \\
\mathbf{m}\end{array}$ \\
\hline & & & 15 & 10 & 10 \\
\hline \multirow{2}{*}{7} & \multirow{2}{*}{ Life Time } & \multirow{2}{*}{15} & High & Medium & $\begin{array}{c}\text { Mediu } \\
\mathbf{m}\end{array}$ \\
\hline & & & 15 & 7 & 10 \\
\hline & Weight & 100 & 85 & 67 & 73 \\
\hline
\end{tabular}

Table (4): Financial Comparison

\begin{tabular}{|l|l|c|c|c|c|}
\hline Item & Unit & & UF & GAC & \multicolumn{1}{l|}{ IEX } \\
\hline \multirow{3}{*}{ Capital Cost } & \multirow{2}{*}{ LE } & Civil & $10,290,000$ & $8,750,000$ & $6,650,000$ \\
\cline { 3 - 6 } & & Media & $1,858,660$ & 492,188 & $4,270,833$ \\
\hline \multirow{2}{*}{ Rumning Cost } & \multirow{2}{*}{ LEyear } & Chemical & 689,850 & - & 99,000 \\
\cline { 3 - 6 } & & Power & $1,165,110$ & 79,210 & 178,210 \\
\hline \multirow{2}{*}{$\begin{array}{l}\text { Regeneration } \\
\text { Replacement }\end{array}$} & \multirow{2}{*}{ LE/year } & Reg./Rep. & 154,888 & 32,813 & 385,000 \\
\hline Unit-Cost & & Frequency & 3 & 5 & 3 \\
\hline & LEm & & 0.53 & 0.16 & 0.33 \\
\hline
\end{tabular}


The comparison indicates that the UF system is the most effective method for NOM removal from the technical point of view followed by IEX which present good choice for average sizes plants then GAC with average water quality but suitable for larger plants.

\section{Financial comparison}

The following parameters have been taken into consideration during the preparation of cost estimate which is summarized in Table (6), comparison is conducted on the basis of 10,000 $\mathrm{m}^{3} / \mathrm{d}$ plant capacity.

\section{Capital cost}

All civil, media costs shall be included in this initial cost estimation. Construction of treatment works cost has been estimated based on a price per cubic meter of plant capacity in addition to the price of required media according to the proposed plant location as follows:

Construction (Supply \& Install)

- Glueckstern, stated that for UF membranes, capital costs around $\$ 147$ per $\mathrm{m}^{3}$.

- AWWA 2013, stated that for GAC, capital cost ranges from $\$ 0.25$ to $\$ 0.50$ per gallon.

- ESTCP 2010, assumed that for IEX capital Cost of virgin resin was to be $\$ 246$ per $\mathrm{ft} 3$

Media

- Schäfer 2001, stated that UF membranes costs around $\$ 1500$ while Biotech commercial company offered UF membranes ranging from $\$ 1200$ to $\$ 1500$.

- AWWA 2013, stated that for GAC, media Costs $\$ 1.50$ per pound.

- ESTCP 2010, stated that the cost of virgin IEX resin is $\$ 246$ per $\mathrm{ft}^{3}$.

Chemical Costs

- P. Glueckstern, stated that UF system chemicals costs around 2.70 cent per $\mathrm{m}^{3}$.

- Chemicals needed for GAC systems can be neglected.

- Commercial prices for IEX system chemicals ranges from 3 to $5 \mathrm{LE}$ per $\mathrm{kg}$, (www.alibaba.com).

\section{Operation and maintenance cost}

Cost of O\&M include cost of electric power, lubrication materials, oil, equipment and required manpower to operate and maintain the entire project components.

Cost of electric power and oil required for pumping stations is estimated on the basis of 24 hours per day operation and unit price of $0.5 \mathrm{LE} / \mathrm{kwh}$, including the cost of consumed oil.

The cost of required manpower for O\&M process of pumping station has been neglected in this comparison as all systems are suggested to improve existing current plants which already has their crew.

\section{Replacement and regeneration}

The expected life cycle for the main elements such as filters and media range between 3 to 10 years which after regeneration or replacement must be conducted, while the expected life cycle for the electromechanical elements such as pump stations is between 15-20 years. Accordingly, during the life cycle of plants all elements shall be replaced during the determined design period. Depending on the prior mentioned, Stocks and spare parts shall be allocated reserves to cover the required replacement.

P. Glueckstern, stated that for UF membranes, replacement costs around $\$ 1158$ per year.

- AWWA 2013, stated that for GAC, regeneration Costs $\$ 0.50$ per pound.

- ESTCP 2010, assumed that for IEX resin replacement is estimated to be $\$ 198$ per $\mathrm{ft}^{3}$.

After conducting the financial comparison the results indicates that, GAC is the cheapest method with unit cost of $\left(0.16 \mathrm{LE} / \mathrm{m}^{3}\right)$, followed by IEX $\left(0.33 \mathrm{LE} / \mathrm{m}^{3}\right)$ then UF $\left(0.53 \mathrm{LE} / \mathrm{m}^{3}\right)$. After combining both technical and economical comparisons, it is obvious that GAC technology will most probably get more and more acceptance for application in large water treatment plants.

\section{2- Conclusions and recommendations}

The following conclusions can be withdrawn from the study:

- Existing conventional water treatment plants in Egypt are not designed for removing NOM pollutants, TOC concentration in raw water range from 5.5 to $8 \mathrm{mg} / \mathrm{L}$ and the plants removal efficiency does not exceed $30 \%$.

- NOM compounds are known to react with chlorine and chloramines to produce DBPs such as THMs. NOM causes tastes, odors and color, and present potential health concerns. Water containing Natural organic matter promotes biological growth in distribution systems.

- The best effective technologies for reducing NOM concentrations, minimizing DBPs and can remove selected contaminants of concern with affordable rates are GAC filters, UF membranes and IEX resins. All three suggested technologies produce reasonably good water quality.

- Technical comparison is conducted among the three methods taking into consideration the performance, need for skilled workers, ability to deal with shock loads, waste production, O\&M needed time and life time of the media. The analysis results indicated that the UF is the most effective method from the technical point of view followed by IEX then GAC.

- The financial comparison considered capital cost, running cost and media/membrane regeneration or replacement. The analysis results 
indicated that GAC is the cheapest method ( 0.16 $\left.\mathrm{LE} / \mathrm{m}^{3}\right)$, followed by IEX $\left(0.33 \mathrm{LE} / \mathrm{m}^{3}\right)$ then UF $\left(0.53 \mathrm{LE} / \mathrm{m}^{3}\right)$.

\section{References}

1. A.I. Schäfer, A.G. Fane, T.D. Waite, Cost Factors and Chemical Pre-treatment Effects in the Membrane Filtration of Waters containing Natural Organic Matter.

2. ALL Consulting, Water Treatment Catalog and Decision Tool, Water Treatment Technology Fact Sheet of ion Exchange.

3. AMTA, American Membrane Technology Association, (Feb.2007)

4. Ang, W.S.; Lee, S.; Elimelech, M. (2006). Chemical and physical aspects of cleaning of organic-fouled reverse osmosis membranes Journal of Membrane Science, Vol. 272,Issues 1-2, (March 2006).

5. Brian Boltoa, David Dixonb, Robert Eldridgec, Ion exchange for the removal of natural organic matter, Reactive \& Functional Polymers (2004)

6. Clark, Robert M. Granular Activated Carbon: Design, Operation, and Cost. Lewis Publishers, 1989.

7. Daniel N Creek; James M Davidson, Treating MTBE- impacted drinking water using granular activated carbon; California MTBE Research Partinership; National Water Research Institute (U.S), (Dec.2088)

8. De la Rubia, Ángeles; Rodríguez, Removal of natural organic matter and THM formation potential by ultra- and nanofiltration of surface water, (Feb.2008)

9. DOW, FILMTECTM Membranes, Membrane System Design Guidelines for Commercial Elements.

10. Edwin Zondervan, Intermediate to long term optimization of dead-end ultra ${ }^{-}$ltration E. Zondervan, 2007.

11. ESTCP U.S. Department of Defence, Tailored Granular Activated Carbon Treatment of Perchlorate in Drinking Water, (August 2011)

12. ESTCP U.S. Department of Defence, Integrated Ion Exchange Regeneration Process for Perchlorate in Drinking Water, (August 2010).

13. ESTCP U.S. Department of Defence, Demonstration of Regenerable, Large-Scale Ion Exchange System Using WBA Resin in Rialto, CA (Drinking Water Treatment - Pilot Scale), (August 2008).

14. Gizeshwork Tadesse Gurmu, Impact of Coagulant Type and Ion exchange (IEX) Pretreamnet on Floc Strenght and Structure at the Kluizen WTP, Faculty of Bioscience Engineering,2012.

15. José Miguel Arnal, Beatriz Garcia-Fayos and Maria Sancho, Membrane Cleaning, Instituto de Seguridad Industrial, Radiofisica y Medioambiente (ISIRYM) / Universitat Politècnica de València, Spain.

16. Michael Pilutti, Julia E. Nemeth, Technical and Cost review Of Commercially Available MF/UF membrane Products.

17. Michael Bourke \& Miguel Arias, Ion Exchange for NOM Removal Prior to Membranes Orica Water care Inc,2009.

18. Mohammadi, T.; Madaeni, S.S. \& Moghadam, M.K. (2002). Investigation of membrane fouling. Desalination, Vol. 153, Issues 13, (February 2003).

19. Mohamed Ahmed Reda Hamed, Control of Trihalomethanes (THMs) Formation by Proper Prechlorination System in Water Treatment Plants, Ain Shams University, 2012.

20. MWH, Nubaria Canal Water Pollution, Mitigation of Problems Related to Use and Recycling of Drainage Water of Nubaria Canal Water for Treated Potable Drinking Purposes, Situation Analysis Report, (January 2009)

21. P. Glueckstern and M. Priel,Mekorot, Comparative Cost of UF vs. Conventional Pretreatment for SWRO Systems, Water Co., TelAviv.

22. Pete D'Adamo, Powdered and Granular Activated Carbon Treatment for TOC Reduction and Stage 2 D/DBPR Compliance, NC AWWA-WEA Spring Conference Wilmington, NC, April 15, 2013.

23. Reynolds T.D., and Richards P.A (1996). Unit Operations and Processes in Environmental Engineering, 2nd Edition. PWS Publishing Co., New York, NY. Water Treatment Technology, Fact Sheet.

24. Shirra Gur-Reznik, Ilan Katz, Carlos G. Dosoretz, Removal of dissolved organic matter by granular-activated carbon adsorption as a pretreatment to reverse osmosis of membrane bioreactor effluents. Faculty of Civil \& Environmental Engineering and GrandWater Research Institute, Technion-Israel Institute of Technology, Haifa 32000, Israel

25. W. S. Miller, GE Water \& Process Technologies, C. J. Castagna and A. W. Pieper, The Permutit Co., Inc, Understanding IonExchange Resins For Water Treatment Systems, (June-2009).

26. Zimmer, G., Crittenden, J.C., Sontheimer, H., and Hand, D., 1988. "Design Considerations For Fixed-Bed Adsorbers That Remove Synthetic Organic Chemicals In The Presence of Natural Organic Matter," Proceedings of AWWA Conference, Orlando, Florida, June, p. 210-219.

\section{List of Symbols}

$\begin{array}{lll}\text { AWWA } & \begin{array}{l}\text { American Works } \\ \text { Association }\end{array} \\ \text { NOM } & \text { Normal Organic Matter } \\ \text { TOC } & \text { Total Organic Carbon } \\ \text { BOD } & \text { Biochemical oxygen demand } \\ \text { COD } & \text { Chemical Oxygen Demand } \\ \text { IEX } & \text { Ion Exchange } \\ \text { MF } & \text { Microfiltration } \\ \text { UF } & \text { Ultrafiltration } \\ \text { GAC } & \text { Granular Activated Carbon } \\ \text { PAC } & \text { Powder Activated Carbon } \\ \text { WTP } & \text { Water Treatment Plant } \\ \text { THMs } & \text { Trihalomethanes } \\ \text { DBPs } & \text { Disinfection by Products } \\ \text { ESTCP } & \text { Environmental Security } \\ & \text { Technology Certification Program } \\ \text { AMTA } & \text { American Membrane Technology } \\ & \text { Association } \\ \text { MWH } & \text { Montgomery Watson Harza } \\ & \text { Company }\end{array}$

